\title{
Fifty years of protein research: Personal experiences
}

\author{
M.R. Jisnuson Svasti \\ Laboratory of Biochemistry, Chulabhorn Research Institute, 54 Kamphaeng Phet 6, Talat Bang Khen, Laksi, \\ Bangkok 10210 Thailand \\ e-mail: jisnuson@cri.or.th
}

\begin{abstract}
The present article is a recollection of my career in science over the past 45 years, which has focused on protein science ever since my PhD study in Cambridge, UK. Upon return to Mahidol University, research initially focused on proteins involved in male reproduction and later turned to glycosidase enzymes in plants. This focus led to the establishment of the Centre for Excellence in Protein Structure, the first centre on protein research in Thailand. My interests included abnormalities in proteins giving rise to diseases such as genetic diseases and cancer, which is now the focus of the laboratory of biochemistry at the Chulabhorn Research Institute. In addition to research, I have always enjoyed working for scientific societies at national and international level, where I have served as President of the Federation of Asian and Oceanian Biochemists, President of the Science Society of Thailand, and founding President of the Protein Society of Thailand.
\end{abstract}

KEYWORDS: collaboration, international cooperation, society, protein science, biochemistry

\section{INTRODUCTION}

I am honoured to write this article for ScienceAsia on the 70th Anniversary of the Science Society of Thailand (SST) under Patronage of Rama IX, since I have worked with the society for 45 years and served as the Editor of ScienceAsia (2001-2007) and its predecessor the journal of the Science Society of Thailand (JSST) (1985-1987). This article will focus on my own interests in protein research, and in part on the development of protein science in Thailand.

\section{Study at Cambridge, UK}

I was born just a few months before the foundation of SST and studied in England from the age of 6 years old until finishing my Ph.D. in 1972. I became interested in protein chemistry during my undergraduate studies for a B.A. (Hons.) degree in biochemistry at the University of Cambridge, UK (1965-1968). Like other graduates, I wanted to study for my Ph.D. at the MRC Laboratory of Molecular Biology (LMB), Cambridge, UK due to their excellent facilities. The LMB was founded in 1964, in recognition of the importance of molecular biology, as shown by 3 Nobel prizes awarded to Cambridge scientists: the 1953 Chemistry prize awarded to Frederic Sanger for protein sequencing; the 1962 Physiology or Medicine Prize awarded to Max Perutz and John Kendrew for the 3Dstructure of haemoglobin and myoglobin; and the 1962 Chemistry prize awarded to Francis Crick and James D. Watson for the DNA double helix.
When I started my Ph.D. research at LMB 50 years ago, Sanger had already started work on nucleic acid sequencing and later received his second Nobel Prize for chemistry in 1980. Hence I decided to work with Cesar Milstein (Fig. 1a), a biochemist from Argentina, who was using protein chemistry to study immunoglobulin sequences to understand how protein structure determines function. The first year was rather stressful, because Cesar's project to determine sequence variation in human antibodies with different specificity was very difficult, since no techniques were available then for obtaining accurate sequences of peptide mixtures: nowadays, recent advances in mass spectrometry may make this possible. Thus my thesis work switched to sequence analysis of the mouse myeloma protein MOPC21, including sequencing the kappa light chain ${ }^{1}$, parts of the heavy chain ${ }^{2}$, as well as the arrangement of disulphide bonds ${ }^{2,3}$. This work used not only serum from the mouse, but also fluids from cultured MOPC21-P3 cells, allowing the use of radioisotope labelling.

The availability of cultured cells allowed Milstein and Kohler to fuse MOPC21-P3-X63Ag8 cells with normal spleen cells from mice immunized with sheep red blood cells, resulting in hybrid cells which could produce antibody to SRBC. The discovery of this hybridoma technology allowed the production of monoclonal antibodies of defined specificity, which was a major milestone, resulting in the award of Nobel Prize in Physiology and Medicine to Kohler and Milstein in 1984. Furthermore, although the purpose of the work was basic research, which 


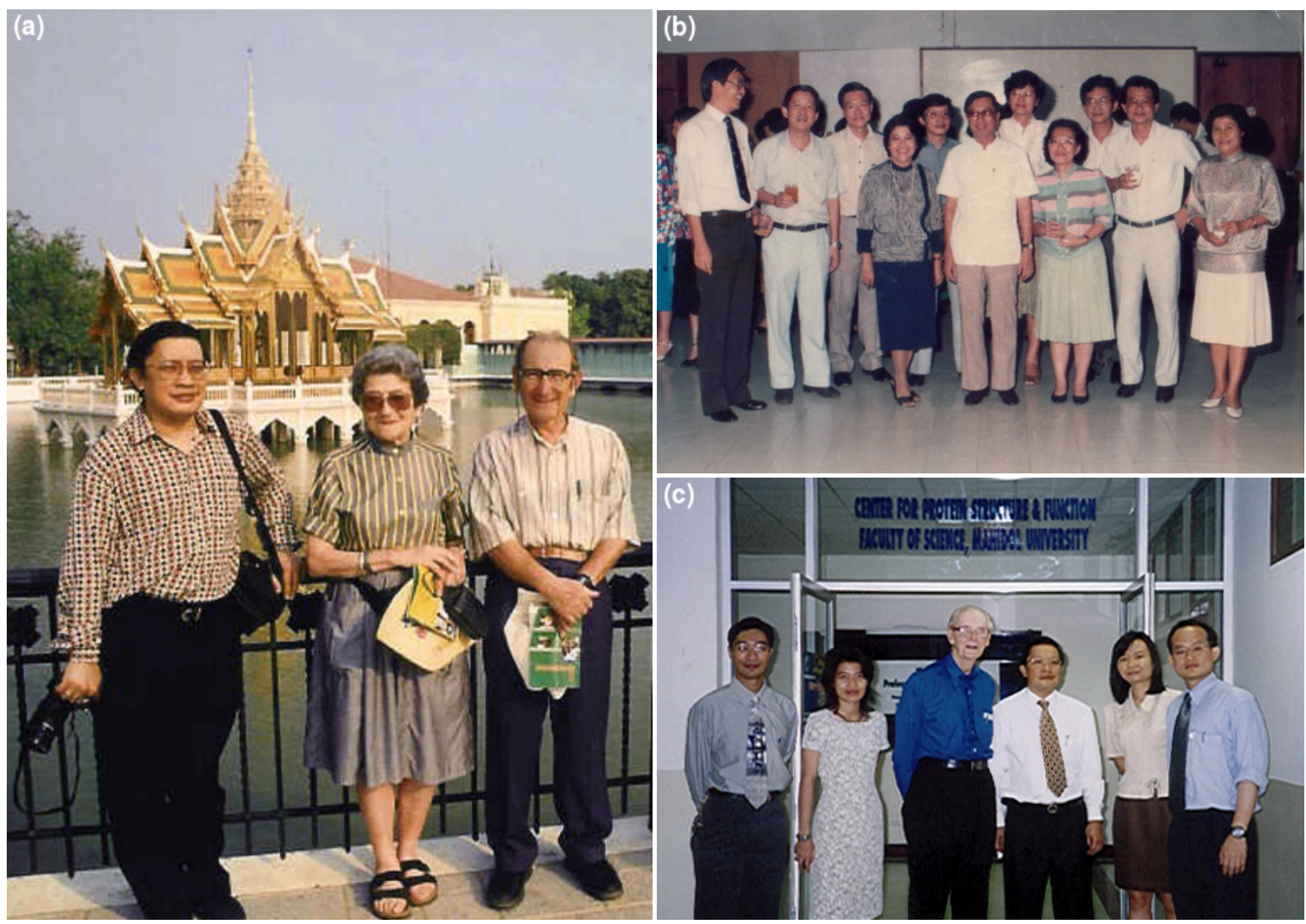

Fig. 1 Staff and researchers from Cambridge and Mahidol University: (a) with my advisor Cesar Milstein and his wife Celia, while visiting Bangkok; (b) staff of the Biochemistry Department, and Dean of the Faculty of Science, Mahidol University; (c) members of the Centre of Excellence in Protein Structure and Function with William N. Lipscomb.

aimed to provide new knowledge, monoclonal antibodies have now become major drugs today, accounting for $\$ 74$ billion sales in 2013 , with the top product having sales of $\$ 11$ billion $^{4}$. Hence no country should neglect the support of basic research.

\section{Department of Biochemistry, Faculty of Science, Mahidol University}

Upon graduation in 1972, I became a staff member at the Biochemistry Department, Faculty of Science, Mahidol University, Bangkok. The university has origins in the first medical school in Thailand at Siriraj Hospital (started in 1889) and was founded as the University of Medical Sciences in 1943, before being renamed Mahidol University in 1969. Then in 1958, the Faculty of Science was established, with Professor Stang Mongkolsuk as Dean, to become a centre for preclinical and postgraduate studies, receiving excellent support from the Rockefeller Foundation in terms of facilities and staff (Fig. 1b). Since there were several foreign staff, teaching was in English when I arrived, which was fortunate since my Thai was not very good. As foreign staff left, young Thai graduates trained overseas like myself replaced them. When I arrived, the head of department, James A. Olson, kindly ordered essential equipment for research, such as high-voltage paper electrophoresis for two-dimensional separation of peptides on paper. Although I wanted to continue research on antibodies, it would be difficult to compete in a forefront area working in Thailand, so we found a niche area studying water-buffalo immunoglobulins. Thus a student laboratory project was published in this journal JSST, and another paper in a good journal showed an addition in the Cterminal peptide, being the first peptide sequenced in Thailand ${ }^{5}$.

After about a year, Olson returned to USA, and Serene Vimokesant, who was much more senior than us, became head, and helped young researchers to obtain overseas funding, which was essential since local funding was very small. The department already had two research groups, on Nutrition (primarily vitamin $\mathrm{A}, \mathrm{B}_{1}$, and $\mathrm{E}$ ) and 
an Amoeba group. A joint grant with young researchers, initially Montri Chulavatnatol, Sakol Panyim and myself led to the formation of the Reproductive Biology Group, which expanded with the return of more young staff, Nongnuj Tanphaichitr, Dhirayos Witisuwannakul, and Vichai Boonsaeng between 1973 and 1975. At that time, birth control using contraceptive drugs was readily available in females, but no such drugs existed for males, who had to rely on condoms or vasectomy. Hence the rationale was to study the biochemistry of male reproduction, especially the differences in proteins and enzymes of somatic cells compared to those of germ cells, with the aim of identifying possible targets for anti-fertility drugs. Thus in retrospect, the Reproductive Biology group was probably the first protein research group in Thailand. The group had several advantages, first was that it was niche area, making it easier to compete internationally, and at the same time, the problem was of global interest due to problem of overpopulation, allowing us to obtain overseas funding from the Rockefeller Foundation, W.H.O. and the Ford Foundation. In addition, the group approach created the necessary critical mass for successful research, and the complementarity in expertise of researchers enabled a broader range of techniques. Finally, being in a developing country also had advantages in terms of availability of specimens, such as spermatozoa and tissues.

At that time, the Faculty of Science at Mahidol University (FSMU) was relatively well equipped compared to other similar faculties, because its role in training postgraduate staff for up-and-coming universities required strong research. However, returning from Cambridge was a still a shock, since some essential equipment for protein research was still lacking, but we must do the best we can with the facilities available. In my case, there were no amino acid analysers in Thailand, so I sent peptide hydrolysates for Milstein to analyse. Nowadays, I keep telling my younger colleagues "Never give up!". Do what you can with the equipment that is available and ask former advisers or colleagues to help when needed.

Despite such limitations, the Reproductive Biology group showed good productivity, as in examples of some publications ${ }^{6-10}$. Over the years, my own work covered several proteins, such as human sperm protamines ${ }^{11}$, testis specific histones, LDH$\mathrm{X}^{12}$, and seminal plasma acidic proteinase. Later, Nongnuj Tanphaichitr and I joined with Prasert Sobhon of the Anatomy Department, recognizing the importance of cross-disciplinary collaboration. We first focused our work on changes in chromatin and nuclear basic proteins during spermatogenesis ${ }^{13}$, and later studied the anti-fertility of gossypol from cotton seed ${ }^{14}$. Our collaboration was recognized by the award of the Mahidol University Prize for Excellence in research in 1982. I was very happy to receive this award personally from H.M. Rama IX, since I obtained my bachelor and doctoral degrees abroad, and unlike graduates in Thailand, never had received a degree from His Majesty.

Equally important, the department and Faculty of Science produced many M.Sc. and Ph.D. graduates, who became the early founders of several departments of biochemistry and related fields throughout Thailand. Research facilities at newer universities were often even more limiting than those at Mahidol University. Hence when a graduate said that they could not do research due to lack of equipment, Bhinyo Panijpan and I became interested in biochemical education, and showed that publishing education-related articles in international journals was possible, with little or no equipment ${ }^{15,16}$. Our efforts stem from my belief that university staff should do research since research and teaching are two sides of the coin of knowledge. Thus research gathers new knowledge to benefit mankind, while teaching disseminates knowledge, and in teaching, we must distill this knowledge for the student, which may raise new questions to study in research. Hence research and teaching cannot be separated, any more than the head and the tail of a coin.

After 4-6 years in Thailand, I did postdoctoral research with Barbara Bowman at the University of Texas Medical Branch in Galveston, Texas, for 15 months studying the molecular differences responsible for the variants of human group-specific component (GC), which had recently shown to be identical to plasma vitamin D binding protein. My work in Texas showed both genetic and glycosylation differences as being responsible for the observed variants ${ }^{17}$. In fact, the reason for going to Texas was to explore the possibility of settling abroad, but although Barbara offered me a position and a green card, I declined and returned to Thailand because my extended family were based here, and this was the same reason for returning from Cambridge in 1972.

\section{Glycosidase enzymes}

Another major research area involved glycosidase enzymes, which normally hydrolyse oligosaccha- 


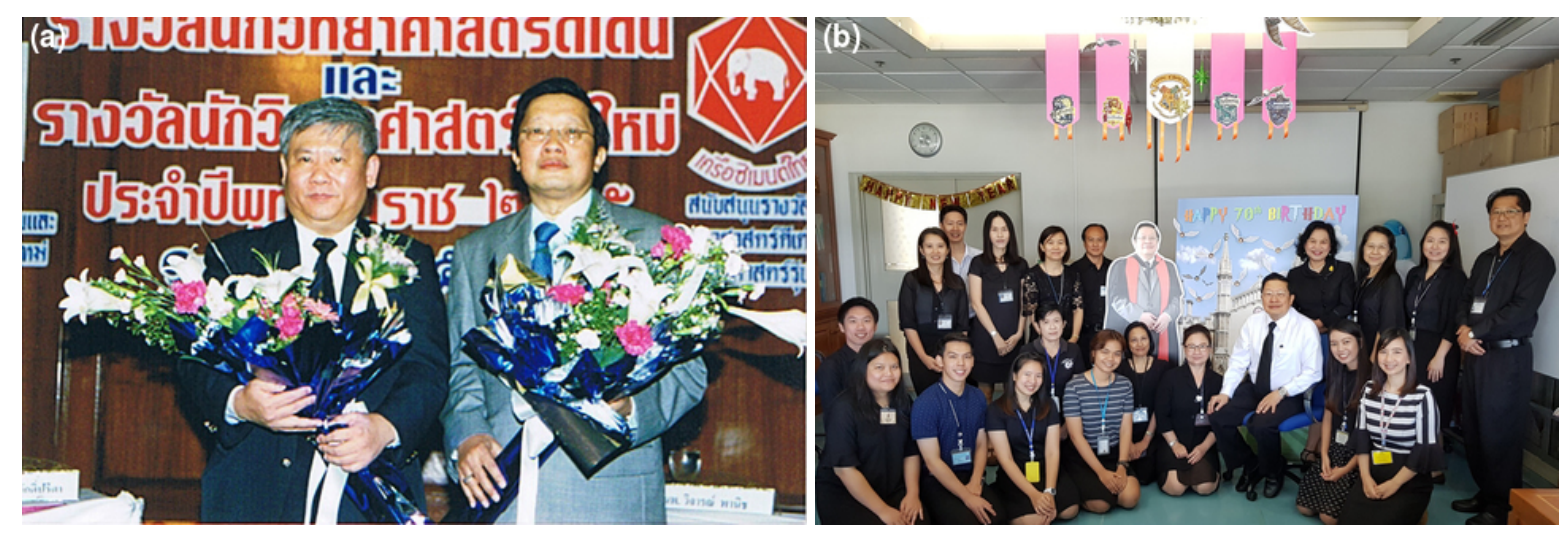

Fig. 2 Researchers involved in study of protein abnormalities giving rise to disease: (a) award of Outstanding Scientist of Thailand to Suthat Fucharoen and myself; (b) researchers at the Chulabhorn Research Institute.

rides, but could potentially be used for synthesis of oligosaccharides and glycosides. Our research began as a Thai-UK collaborative project in biotechnology. I had never worked on glycosidase enzymes before, but agreed to do so since the British counterpart, Christopher Bucke, had previously worked at the sugar company Tate \& Lyle. This started with a visit to the University of Westminster by myself, Rudee Surarit and others to obtain better understanding of research on glycosidases, since several glycosides are of commercial interest. Initially, research funding for joint projects was provided by the Royal Society for the UK group and by the National Research Council of Thailand for the Thai group. Later joint funding was obtained from the European Union. Initially, work in Thailand started with screening for glycosidase enzymes (such as $\beta$ glucosidase, $\alpha$-mannosidase, and $\beta$-galactosidase) from plant seeds. Interesting enzymes were purified, their catalytic properties studied, their substrates identified, and their potential for reverse hydrolysis and transglucosylation explored.

My own interests focused on the $\beta$-glucosidases, since we had been studying cassava $\beta$-glucosidase (linamarase), which hydrolyses the cyanogenic glucoside linamarin leading to cyanide toxicity in cassava. Screening studies, showed that Thai plant seeds contained $\beta$-glucosidases, especially Thai Rosewood (Dalgergia cochinchinensis Pierre) seeds with high content of a $\beta$-glucosidase ${ }^{18}$, which we purified and named dalcochinase. We then studied the kinetic properties, cloned and sequenced the enzyme, and characterized its substrate as an isoflavonoid glucoside. Although cassava linamarase and dalcochinase showed $44 \%$ sequence homology, they differ in many properties, such as natural substrate, ability to form glucosides by transglucosylation, and ability to catalyse reverse hydrolysis. This raises interesting questions in terms of structure-function relationships.

This work on glycosidase enzymes continued until I stopped having a laboratory at Mahidol University around 2005, when I became Dean of the Faculty of Graduate Studies. However, several former students (e.g., Dumrongkiet Arthan) and postdoctoral researchers (e.g., Prachumporn Toonkool Kongsaeree) have continued to study glycosidases until the present day. Furthermore, Wipa Suginta later received the M.R. Jisnuson Svasti-Biochemistry and Molecular Biology Section Award for her excellent work on chitinases. Most notably, James Ketudat-Cairns has done outstanding work on the structure and function of rice $\beta$-glucosidases ${ }^{19}$, which was awarded the first M.R. Jisnuson Svasti Outstanding Protein Scientist Award in 2017.

\section{Protein changes leading to human disease}

Since proteins play a major role in almost all biological processes, defects in their structure and changes in the level of expression of proteins can give rise to diseases. We have explored two areas, namely, genetic diseases and cancer, and these areas have now become the major areas at my laboratory at the Chulabhorn Research Institute (CRI), Fig. 2b, with the overall idea that understanding the molecular bases of such defects may help prevent and/or treat such diseases.

\section{Genetic diseases}

I was already interested in genetic diseases since my Ph.D. studies, because the effects of mutations help us to understand the functional role of the amino acid residue involved in the normal protein. On return to Bangkok, I considered study- 
ing haemoglobin diseases, but Dr Sanga Pootrakul was doing excellent work characterizing abnormal haemoglobins by protein chemistry. But he died very early due to a road accident, so I began collaborating with Suthat Fucharoen on haemoglobin diseases for many years ${ }^{20}$. Later, we shared the most prestigious science award in Thailand, the Outstanding Scientist of Thailand Award from the Foundation for the Promotion of Science and Technology in 2004, Fig. 2a, Suthat primarily for his work on thalassaemia and myself for research on protein structure, function, and abnormalities.

As DNA technology developed, other researchers studied haemoglobin mutations using gene technology, so we switched to study inborn errors of metabolism, arising from deficiencies of enzymes in metabolic pathways. Typically, we collaborate with pediatricians, such as Pornswan Wasant (Siriraj Hospital) and Duangrurdee Wattanasirichaigoon (Ramathibodi Hospital), to analyse the levels of deficient enzymes and detect mutations in genes causing the diseases. A major interest includes lysosomal storage diseases ${ }^{21}$, where enzyme deficiency causes accumulation of substances leading to organ damage and physical defects. Mutations include splicing variants, crossing-over, nonsense and missense mutations. We also study organic acid disorders ${ }^{22}$, such as methylmalonic acidemia (MMA), caused by defective function of the vitamin $\mathrm{B}_{12}$-dependent enzyme methylmalonyl CoA mutase, due to defects in mutase enzyme or in coenzyme metabolism. Some inborn errors of metabolism may cause severe clinical manifestations, such as mental retardation or developmental abnormalities, and sometimes, devastating effects can be avoided through proper treatment, so early detection is important. In addition, as with abnormal haemoglobins, some mutations found in Thailand have not been found elsewhere, so mutations need to be studied locally.

\section{Cancer}

Cancer is initiated by accumulated mutations and proliferation to form a tumour, which may spread to other tissues in a process called metastasis. Often cancers may be cured if diagnosis and treatment are made early, but few biomarkers for cancer are available. Our group was the first in Thailand to use the technique of proteomics, where the proteome patterns (or total protein present at any tissue or cell) are compared and differences analysed. Mass spectrometry is essential for this analysis, so initially we collaborated with Brigitte Wittman-Liebold in
Berlin, until we obtained a QTOF mass spectrometer at CRI in 2005. Initial studies, together with Phramongkutklao Hospital, showed that increased expression of proteins, cathepsin $B$ and prohibitin, was observed in neoplastic thyroid diseases compared to non-neoplastic diseases, such as goitre or nodular hypoplasia ${ }^{23}$, while high expression of galectin-3 correlated with metastatic potential. Proteomics has been extended to study cell lines from cancers common in Thailand such as hepatocellular carcinoma (HCC-S102 cells) and cholangiocarcinoma (HuCCA1 cells), and potential biomarkers found to distinguish the two cancer types. We also use proteomics to study chemical modifications of amino acids, such as O-GlcNAc (O-linked $\mathrm{N}$-acetylglucosamine), which may affect control processes involving phosphorylation.

As the tumour grows, it becomes hypoxic, inducing the formation of new blood vessels (angiogenesis) to provide oxygen and nutrients. In addition, during chemotherapy, cancer cells may become resistant to drugs. Cancer cells can also acquire invasiveness, leading to metastasis or spread to other tissues, which makes treatment even more difficult. Since conventional chemotherapy can cause toxicity, it can only be administered for short periods, after which cells grow again. Our approach is to study non-toxic compounds which can prevent or suppress cancer cell invasion, so may be used for long-term treatment. Thus vanillin, the flavouring agent in vanilla, inhibited invasion of 4T1 mouse breast cancer cells in vitro and reduced in vivo metastasis $^{24}$.

We also use cultured cancer cells to study various phenomena and processes, such as drugresistance, the effects of hypoxia, loss of cell attachment, and vasculogenic mimicry. All these processes involve the action of proteins, especially those involved in signalling pathways which act as control systems. Then we further study the proteins and enzymes involved, with a view to discovering targets for chemotherapy. We also study the effects of natural products or synthetic agents on these processes, including the proteins involved to explore potential anti-cancer drugs.

\section{Centre for Protein Structure and Function (2001-2012)}

In 2000-2001, the Faculty of Science at Mahidol University constructed a new building for use as student laboratories, central equipment facility, and research centres. Hence I submitted a proposal for a new research centre, named the Centre of Ex- 
cellence in Protein Structure and Function (CPSF), Fig. 1c. With establishment of CPSF, major equipment was provided from government funds to furnish the building, most notably X-ray diffractometer, stop-flow enzyme kinetics, FPLC and other essential equipment. The first two items were the first of their kind in Thailand, and without them, it would have been difficult for young researchers to continue research in their area of expertise. Hence establishing research centres as part of a construction program is an effective way of acquiring expensive equipment, which is often difficult to justify as part of a research grant.

This centre consisted of myself as head, together with 4 young staff from three departments, Biochemistry, Chemistry, and Biotechnology. The group had diverse but complementary expertise, with myself interested in protein chemistry and enzymology, and working on glycosidase enzymes. Jirundon Yuvaniyama and Palangpon Kongsaeree had training in structural biology and were working on enzymes for synthesis and modification of penicillins, as well as collaborating on malarial enzymes with Yongyuth Yuthavong's group at BIOTEC, which acquired X-ray diffraction equipment at a similar time. Pimchai Chaiyen had expertise in pre-steady state enzyme kinetics, focusing her work on flavin-containing oxygenases. Pramwadee Wongsaengchantra wanted to isolate proteases specific for sericin, for use in degumming of silk.

Overall, this investment in equipment worked well, since Jirundon, Palangpon and Pimchai later received the Outstanding Young Scientist Award, and then in 2016, Pimchai Chaiyen ${ }^{25}$ followed my footsteps to receive the most prestigious Outstanding Scientist of Thailand Award. Other young scientists joined the centre at various times, namely, Kittisak Yokthongwattana, Danaya Pakotiprapha, and Sittinan Chanarat.

\section{Laboratory of Biochemistry, Chulabhorn Research Institute (1987-present)}

The Chulabhorn Research Institute (CRI) was founded by Her Royal Highness Princess Chulabhorn in 1987 to commemorate the 60th Birthday Anniversary of His Majesty King Bhumibol Adjuyadej, with the goal of using science and technology to improve the quality of life of the Thai people. I was asked to head the Laboratory of Biochemistry at CRI, while retaining my position at Mahidol University. Initially, we used my laboratory at Mahidol University, and I was joined by Chantragan Phipobmongkol as the first recruit. Then in 1992, new laboratory was started at the Chemistry Building at CRI, which benefited from a large equipment grant from the Japan Society for the Promotion of Science, which included an Amino Acid Analyser, and the first Automated Protein Sequencer in Thailand, allowing more peptide and partial protein sequences to be determined. We moved to the new Biomedical Sciences building in about 1999, which was also was well equipped. Work in the early days continued the work at Mahidol University on glycosidase enzymes, as well as the haemoglobin diseases. Later, we gradually stopped working glycosidases, leaving this area to collaborators, and concentrated our work at CRI on protein changes which give rise to disease, such as inborn errors of metabolism and cancer, since we felt that work on diseases was more relevant to the improving quality of life of the Thai people.

\section{Thailand Research Fund (TRF) Senior Research Fellow (2001-2007)}

The TRF Senior Research Fellow grant is a prestigious research grant, with the purpose of providing funds for senior scientists to help, encourage and mentor young researchers. The title of my proposal "Protein Structure and Molecular Enzymology" helped to emphasize proteins and enzymes as a research area, rather than academic subjects like biochemistry or problems-based research such as malaria. This enabled me to draw 18 researchers (including 4 young scientists) from 10 universities in Thailand into the research programme. This included the four young researchers from CPSF and several others from various departments/faculties of Mahidol University, other universities in Bangkok (Kasetsart, Srinakarintwirot), as well as provincial universities (Chiang Mai, Khonkaen, Mahasarakham, Mae Fah Luang, Naresuan, Prince of Songkhla, Suranaree, and Silpakorn).

Research areas covered three main themes. Structure-Function Studies included: glycosidase enzymes; enzymes for synthesis of penicillin derivatives; kinetics of flavoprotein oxygenases; design of chemical proteases; reptile anti-microbial proteins; adaptation of algae to stress; acetyl CoA carboxylase; proteomic studies of moulting in tiger prawn. Protein Changes in Human Disease included: mutations in genetic diseases; protein changes in cancers; protein expression of cells in response to anti-cancer or wound healing compounds. Applications of Enzymes in Biotechnology included: sericinspecific protease for degumming silk; naringinase for removing bitterness from fruit juices; cellulase 
for isolating amorphous silica from rice husk. Thus the "Protein Structure and Molecular Enzymology" title allowed a very broad coverage of research areas, due to the important roles of proteins in biological processes.

Founded in 1992, The Thailand Research Fund (TRF) has been very successful in supporting research to create knowledge at local and national levels. TRF has several programs, but two come to mind in advancing research in Thailand. First the Royal Golden Jubilee (RGJ) Ph.D. scholarships, started in 1996, played an important role in creating qualified manpower for research, having produced some $3200 \mathrm{Ph}$.D. graduates, with some 2000 more students still studying. Interestingly, RGJ Programme first selects active and productive researchers as thesis advisors, and provides scholarships for them to accept Ph.D. students, who work with the Thai advisor but are also funded to work with an overseas collaborator for 6-12 months. This helps to strengthen the research of the advisor, ensures that the student is working on topics of local relevance, and makes the scholarship more attractive. Then, in terms of grants to support basic research, the Academic Research Section of TRF provides grants at three levels to Ph.D. graduates, (a) young researchers who obtained Ph.D. in the last five years (TRF New Researcher), mid-career researchers (TRF Research Scholar), and senior researchers (TRF Senior Researcher Scholar), with the last level being very prestigious. Although the amount of funding and the number of grants awarded are not large, TRF has made a major impact on basic research in Thailand, by providing an ecosystem for researchers at all levels to interact. This includes requirement for young scientists to have mentors and for Senior Scholars to hold annual workshops, as well as major TRF congresses, such as the RGJ Congress and the Young Researcher and Senior Scholars Meeting.

\section{Scientific societies and organizations at national and international level}

I have also enjoyed working with scientific societies at national and international level. Thus I served as Treasurer (1980-1986) and President (1990-1992) of the Federation of Asian and Oceanian Biochemists and Molecular Biologists (FAOBMB), which was founded in 1972 and has some 20 biochemical societies in the Asian and Pacific region as its members ${ }^{26}$ (Fig. 3a). As President, I tried to address important problems common to all academic organizations. First, to improve communication, I wrote a monthly letter to Council Members and supported the production of a Newsletter, both of which had to be sent by regular post, since email and websites were still not available. Then to make FAOB official, I helped to arrange the formal registration of FAOB Inc. as a tax-free association in Australia: providing a legal basis for the organization, which is now essential for opening of bank accounts. All organizations need funds, so I started a Special Member scheme to invite companies to become members, and helped to raise funds through Endowments, such as for lectureships, including starting the Jisnuson Svasti Lecture to be held at each Triennial Congress. From the present website, I am very happy to see that FAOBMB has developed considerably, having sufficient funds to undertake a whole range of activities. Then, when I was Past President, FAOBMB approved a request by Zafar Zaidi (Pakistan) for partial support of an International Conference on Protein Structure and Function in Karachi in 1993, organized by the HEJ Institute of Chemistry, with M. Atta-ur-Rahman as Director. Attending on behalf of FAOBMB was a great experience, so I continued to attend each biennial conference, bringing a young researcher with me each time. Then, conditions for research in most Pakistan laboratories (except HEJ) were not easy, but researchers tried their best despite difficulties, so this was a lesson for the young Thai researchers. Perhaps surprisingly, the meeting attracted some of the best protein scientists in the world, so I made connections with prominent protein researchers Robert Huber, Sir Tom Blundell, John Markley, and Brigitte Wittman-Liebold. We also met several Pakistani scientists, such as Nikhat Ahmed Siddiqui, with whom I am still in contact. Zaidi became the Vice-Chancellor of the University of Karachi and later died. Three years after his death, I attended his Memorial Symposium, organized by Attiya Abbhasi, together with by local and international colleagues. Overseas participants visited Zaidi's grave, strewed rose petals, and stood in silence around the grave remembering their old friend who had brought them all together. This made me realize that despite differences in race, religion, and country of origin, science unites us all, so we can work together to build a better world.

The member society of FAOBMB in Thailand is the biochemistry and Molecular Biology Section (BMB), a section of SST, founded in 1973. Since protein research is a part of biochemistry, I have been involved in BMB (and consequently SST) from the start and served as Chairman of BMB in 19861987. Initially, BMB was mainly involved in ar- 
ranging Teachers' Training workshops, co-hosted by biochemistry departments in Thailand. Major activities now include the biennial conferences, and workshops in intervening years at the Annual Conference of SST. Importantly, BMB successfully hosted the 3rd FAOB Congress in 1983, opening up the biochemical activities of Thailand to the outside world, and with it making many friends. Later, BMB organized FAOBMB meetings in 1994, 2004, and 2012. BMB has also initiated awards, the Young BMB Award for those under 35 and the M.R Jisnuson Svasti-BMB Award (which I helped to endow) for those under 45. Most of all, BMB is a family, of which I feel warm to be a part. Many were former graduate students in the Department of Biochemistry at Mahidol University. Several, such as Tipaporn Limpaseni, played important roles in the administration of SST, and my former advisee Piamsook Pongswasdi served as FAOBMB Treasurer for 2 terms, as I did.

The establishment of CPSF and the award of the TRF Senior Research Scholar grant in 2001 helped to focus attention on protein research. Hence a Thai Protein Research Network, affiliated with BMB, was started in December 2001 to exchange news between protein researchers, operating through an email server at the Synchrotron Light Research Institute (SLRI) at Nakhon Ratchasima. Then I invited Professor William N. Lipscomb, Nobel Laureate in chemistry, then aged 83, to visit CPSF as Stang Mongkolsuk Distinguished Professor of the Faculty of Science, Mahidol University, for the period 16 June 2002 to 15 September 2002. During his stay, Professor Lipscomb lectured not only at Mahidol University, but at 9 other universities in Bangkok and the provinces, as well as at the Ministry of Science and science-related institutions. He was also interviewed for TV and met with the Prime Minister, making tremendous impact, not only on protein research, but also in improving public awareness and support for science. He was awarded the D.Sc. (Hons) from Mahidol University in 2003, and I am honoured to have received the same award in 10 years later.

\section{Protein Society of Thailand}

Since TRF Senior Scholars are required to arrange a workshop/symposium each year, we arranged a Protein Network Symposium on "Protein Structure and Molecular Enzymology", at the Faculty of Science, Mahidol University, 29-30 August 2002, supported by TRF and BMB, with Lipscomb and Yongyuth Yuthavong as Plenary Speakers, followed by 18
Invited Lectures. The Second Protein Research Network Symposium was held on 22-23 September 2005, supported by TRF, FSMU, CRI, and BMB, attracting nearly 400 participants from 16 institutions in Thailand. Since participants voted to form a protein community, we formed the Protein Society of Thailand (PST), initially as an informal club in 2006 , which became formally registered as a society in 2010, with myself as President and Worachart Sirawaraporn as Vice-President.

PST has the goals of strengthening capability in protein research in Thailand, namely, to: exchange expertise and transfer of new technologies among members, to initiate activities with novelty and creativity in field of protein research, to liaise with local and international scientific organizations, and to publicize basic knowledge of protein biochemistry to the scientific community. Membership categories include not only Student Member, Regular Member, Life Member but also Company Member. This derives from my experience as President of FAOBMB, and indeed support from companies has been important in the success of PST.

In the early years, PST helped to promote new technologies by co-organizing workshops, such as sponsoring a Protein Crystallography workshop, organized by SLRI and a workshop in proteomics organized by BIOTEC. These technologies have now developed well, so that there are now some 20 protein crystallography groups and some 80 proteomics groups in Thailand. This has been accompanied by increases in key equipment such as X-ray diffractometer and protein-capable mass spectrometers. In addition, many crystallographers travel to synchrotron facilities in Taiwan, Korea, and Japan. Although the resolution and intensity of the protein crystallography beamline are not sufficient at SLRI, a new crystallization robot should help in preparing protein crystals.

After its foundation, PST organized its First Annual Symposium on "Challenges in Protein Research in Thailand" on 24-25 October 2006, Fig. 3b. These Annual Symposia of the Protein Society are now well established and have continued to be well attended by more than 300 participants each year. An important feature is that these meetings encourage young Ph.D. researchers, by providing them with the opportunity to make oral and poster presentations, as well as helping them to make contacts and be aware of the protein research in Thailand. Prizes are awarded for the best oral and poster presentations. Also important is the company exhibition, where there is a real engagement between participants and 


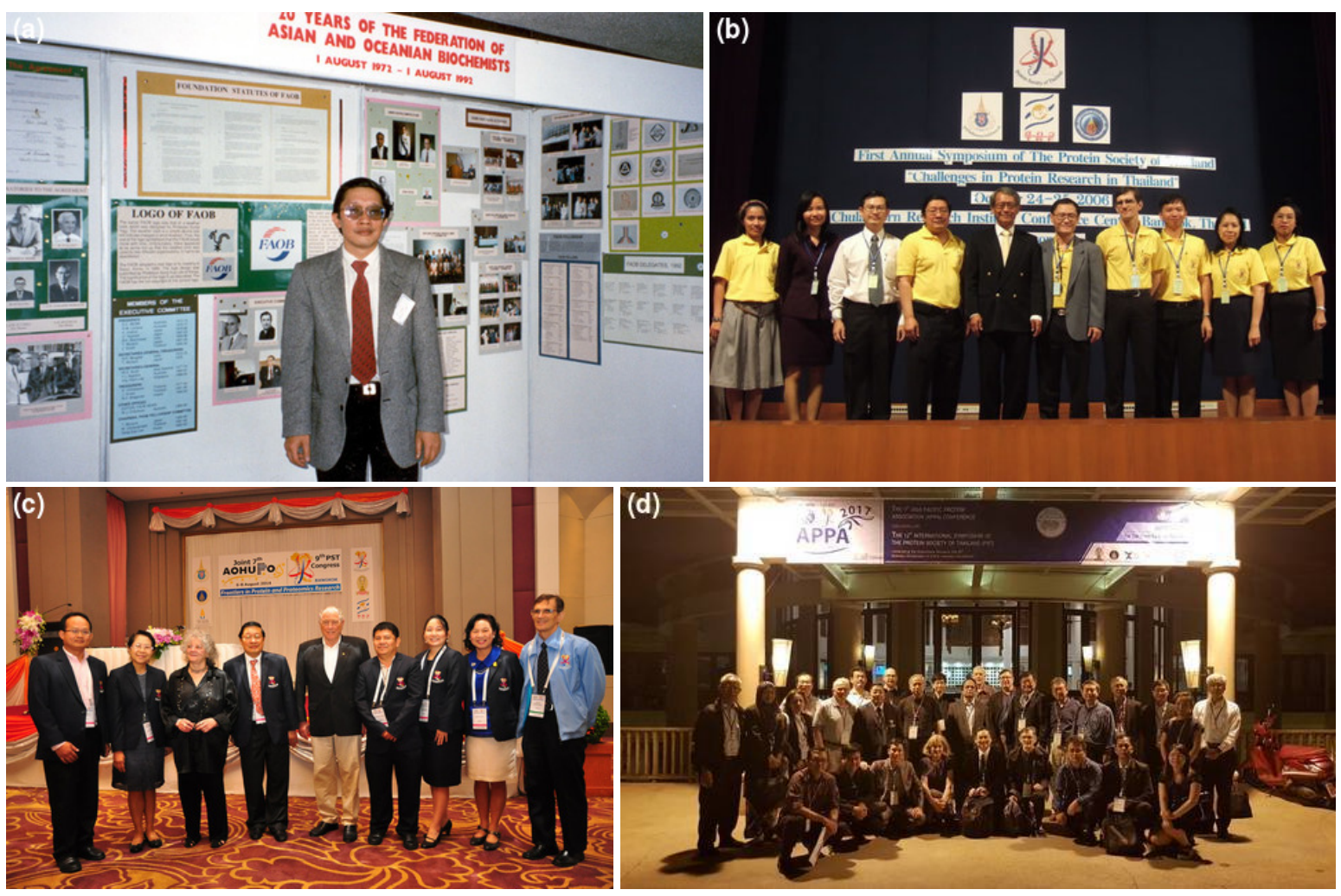

Fig. 3 Working for local and international scientific societies: (a) as President on 20th Anniversary of the Federation of Asian and Oceanian Biochemists; (b) first international symposium of the Protein Society of Thailand (PST); (c) Asian Oceanian Human Proteome Organization conference hosted by PST; (d) Asia Pacific Protein Association conference hosted by PST.

companies, including games and prize draws.

To promote interaction of Thai protein researchers overseas, PST is represented at regional organizations, the Asian Oceania Human Proteome Organization (AOHUPO) and Asia Pacific Protein Association (APPA), and interacts with HUPO (Human Proteome Organization). PST also hosted the 7th AOHUPO/9th PST Conference in 2014 (Fig. 3c) and the 5th APPA/12th PST Conference in 2017 (Fig. 3d), each with a Nobel Laureate speaker, and attended by protein researchers worldwide. Typically, Travel Fellowships are awarded to selected young scientists to attend these international meetings. Now, I now serve as APPA President for 20172018, to be succeeded by Jim Cairns in 2018-2019. Then, in 2020, there are plans to organize a joint meeting between APPA, the Protein Science Society of Japan, and the Protein Society, USA, the first protein society, founded in 1985. These activities will help make protein research in Thailand of global interest.

\section{CONCLUSIONS}

I am glad to have chosen an academic life ${ }^{27}$ and feel honoured to receive the highest award for academics in Thailand, the Dushdi Mala medal. Academics are fortunate to have a chance to do many jobs. Teaching and mentoring keeps us young, because we are always trying to help young people develop. Research focuses the mind in solving problems and appreciating the beauty of protein molecules, whose structure has evolved to fulfil various important roles in living organisms. Administration can be challenging, since we must manage the organization to achieve desired objectives, but we can enjoy supporting research and encouraging researchers. Lastly, I have enjoyed involvement in many scientific organizations, both locally and internationally, because we can all work together, despite our differences, to help the advancement of mankind.

My research on proteins has focused on basic 
research. Indeed, I have always believed in the importance of basic research in generating new knowledge and ideas, which may have important applications in the future, such as in the work of my advisor Cesar Milstein. This belief is shared by several Nobel Laureates, such as Robert Huber, William N. Lipscomb, and J. Fraser Stoddart, who were all approached by industries interested to develop their research into products. In Thailand, support for research has been variable, and sometimes subject to political influence, such as a $50 \%$ decrease in project funding with a change of government. Recent government emphasis on applied research to make products, ostensibly "to help Thailand to escape the middle-income gap", has been stressful for those engaged in basic research. Doctoral students need to develop knowledge and perspectives of their field, as well as acquire skills enable them to do research of a quality satisfactory to professionals in the field. Young Ph.D. graduates also need to develop their reputation by basic research leading to publications and citations. We must not neglect the young scientists who represent the future of our nation. In addition, publications and citations from basic research plays an important role in most world university ranking systems, so lack of support for basic research will lead to poorer performance of Thai universities.

With these thoughts in mind, I would like to close with a quotation from the famous report of Vannevar Bush to the President of the US, entitled Science, the Endless Frontier, written in 1945, three years before foundation of SST, which I believe is still true today: "A nation which depends upon others for its new basic scientific knowledge will be slow in its industrial progress and weak in its competitive position in world trade, regardless of its mechanical skill."

Acknowledgements: I would like to express my sincere appreciation to numerous organizations, with which I have worked and/or received financial support. Most of all, I would like to thank my friends, colleagues, and students over these many years for making this life so interesting and enjoyable.

\section{REFERENCES}

1. Svasti J, Milstein C (1972) The complete amino acid sequence of a mouse $\kappa$ light chain. Biochem $J \mathbf{1 2 8}$, 427-44.

2. Svasti J, Milstein C (1972) The disulphide bridges of a mouse immunoglobulin G1 protein. Biochem $J$ 126, 837-50.
3. Svasti J, Milstein C (1970) Variability of interchain binding of immunoglobulins: interchain bridges of mouse IgG1. Nature 228, 932-4.

4. Ecker DM, Jones SD, Levine HL (2015) The therapeutic monoclonal antibody market. $m A b s$ 7, 9-14.

5. Svasti J (1977) An addition at the $C$-terminus of water-buffalo immunoglobulin lambda chains. Biochem $J$ 161, 185-7.

6. Haesungcharern A, Chulavatnatol M (1973) Stimulation of human spermatozoal motility by caffeine. Fertil Steril 24, 662-5.

7. Puwaravutipanich T, Panyim S (1975) The nuclear basic proteins of human testes and ejaculated spermatozoa. Exp Cell Res 90, 153-8.

8. Tanphaichitr N (1977) In vitro stimulation of human sperm motility by acetylcarnitine. Int $J$ Fertil 22, 85-91.

9. Chulavatnatol M, Panyim S, Wititsuwannakul D (1982) Comparison of phosphorylated proteins in intact rat spermatozoa from caput and cauda epididymidis. Biol Reprod 26, 197-207.

10. Boonsaeng V (1981) A simple method to measure the liquefaction rate of human semen. Andrologia 13, 342-5.

11. Pongsawasdi P, Svasti J (1976) The heterogeneity of the protamines from human spermatozoa. Biochim Biophys Acta 434, 462-73.

12. Svasti J, Viriyachai S (1975) The properties of purified LDH-C 4 from human testis. In: Markert CL (ed) Isozymes, II: Physiological Function, Academic Press, NY \& London, pp 113-27.

13. Sobhon P, Chutatape C, Chalermisarachai P, Vongpayabal P, Tanphaichitr N (1982) Transmission and scanning electron microscopic studies of the human sperm chromatin decondensed by micrococcal nuclease and salt. $J$ Exp Zool 221, 61-79.

14. Vongsorasak L, Svasti J (1986) Gossypol prevents activation of purified proenzyme of human seminal plasma acidic proteinase. Biochim Biophys Acta 883, 271-6.

15. Svasti J, Panijpan B (1977) SDS-polyacrylamide gel electrophoresis: a simple explanation of why it works. $J$ Chem Educ 54, 560-2.

16. Svasti J (1980) A simple laboratory experiment in biochemistry: the activation and inactivation of sulphydryl and aspartate proteases. Biochem Educ 8, 11-5.

17. Svasti J, Bowman BH (1978) Human group-specific component: changes in electro-phoretic mobility resulting from vitamin $\mathrm{D}$ binding and from neuraminidase digestion. J Biol Chem 253, 4188-94.

18. Srisomsap C, Svasti J, Surarit R, Champattanachai V, Boonpuan K, Sawangareetrakul P, Subhasitanont P, Chokchaichamnankit D (1996) Isolation and characterization of an enzyme with $\beta$-D-glucosidase $/ \beta$-Dfucosidase activities from Dalbergia cochinchinensis Pierre. J Biochem 119, 585-90. 
19. Chuenchor W, Pengthaisong S, Robinson RC, Yuvaniyama J, Oonanant W, Bevan DR, Esen A, Chen CJ, Opassiri R, Svasti J, Cairns JRK (2008) Structural insights into rice BGlu1 $\beta$-glucosidase oligosaccharide hydrolysis and transglycosylation. $\mathrm{J} \mathrm{Mol} \mathrm{Biol}$ 377, 1200-15.

20. Boontrakulpoontawee P, Svasti J, Fucharoen S, Winichagoon P (1987) Identification of Hb LeporeWashington-Boston in association with $\mathrm{HbE}$ in a Thai female. Hemoglobin 11, 309-16.

21. Suwannarat P, Keeratichamroen S, Wattanasirichaigoon D, Ngiwsara L, Cairns JRK, Svasti J, Visudtibhan A, Pangkanon S (2007) Molecular characterization of type 3 (neuronopathic) Gaucher disease in Thai patients. Blood Cell Mol Dis 39, 348-52.

22. Champattanachai V, Cairns JRK, Shotelersuk V, Keeratichamroen S, Sawangareetrakul P, Srisomsap C, Kaewpaluek V, Svasti J (2003) Novel mutations in a Thai patient with methylmalonic acidemia. Mol Genet Metabol 79, 300-2.

23. Srisomsap C, Subhasitanont P, Otto A, Mueller EC, Punyarit P, Wittmann-Liebold B, Svasti J (2002) Detection of cathepsin B up-regulation in neoplastic thyroid tissues by proteomic analysis. Proteomics 2, 706-12.

24. Lirdprapamongkol K, Sakurai H, Kawasaki N, Choo M-K, Saitoh Y, Aozuka Y, Singhirunnusorn P, Ruchirawat S, Svasti J, Saiki I (2005) Vanillin suppresses in vitro invasion and in vivo metastasis of mouse breast cancer cells. Eur J Pharmaceut Sci 25, 57-65.

25. Chaiyen P, Sucharitakul J, Svasti J, Entsch B, Massey V, Ballou DP (2004) Use of 8-substituted-FAD analogues to investigate the hydroxylation mechanism of the flavoprotein 2-methyl-3-hydroxypyridine-5-carboxylic acid oxygenase. Biochemistry 43, 3933-43.

26. Svasti J, Sawyer WH (2006) Federation of Asian and Oceanian Biochemists and Molecular Biologists Incorporated (FAOBMB Inc.): A brief history. IUBMB Life 58, 280-2.

27. Svasti J (2009) How I became a biochemist: what biochemistry has done for me. IUBMB Life 61, 476-8. 